\title{
ICASH-A044
}

\section{CONTROLLING DIET EXPERIENCE OF DIABETIC PATIENTS IN BUKITTINGGI, INDONESIA}

\author{
Dona Amelia*, Ade Srywahyuni, Liza Merianti, Mita Yulia
}

Stikes Yarsi Sumatera Barat

\begin{abstract}
Background: In 2015, the International Diabetes Federation reported that there were 415 million adults aged 20 to 79 with diabetes. Indonesia is among the 10 countries with the high number of diabetic patients and is ranked 7th in the world with the number of patients reaching 10.2 million. Diabetes management can be done through controlling blood sugar through 4 pillars, namely education, diet, exercise, and medication. However, the current phenomena show that many diabetics have poor dietary control so they fail maintain their blood sugar within its normal limits and are at greater risk for diabetes complications. However, we can still find diabetic patients who are able to improve their diet and control their blood sugar. Therefore, getting information from them, especially related to their experience in controlling their diet, is expected to provide hope and motivation for others. Hence, this study aims to find out and expolore the experience of diabetics with controlled blood sugar and diet

Methods: This study uses a qualitative research method with a descriptive phenomenology approach. The selection of participants was carried out by using a purposive sampling technique. The number of participants in this study were 5 and data were processed through Colaizzi method.

Result: There are four themes obtained in this study namely: Self-commitment to discipline and dietary compliance, Fruit as an alternative appetite suppresant, Controlling hunger as a habit, and Channelling hunger to activities. Controlling diet for participants has been succesfully done by created a new habit through controlling their hunger, so that they could keep their commitment dan disclipline for dietary compliance, choosing fruits as alternative suppresant and doing activity for channeling the hunger. Therefore it is important for the nurses to educate the diabetic patients about how to deal with diet issues through controlling a hunger as a habit
\end{abstract}

Keywords: Diabetes, Diet, Patients' Experience

\section{INTRODUCTION}

Diabetes mellitus (DM) is a chronic disease occuring when the pancreas does not produce enough insulin, or when the body cannot effectively use the insulin produced. It causes an increase in the concentration of glucose in the blood [1]. Poor control of diabetes mellitus can lead to hyperglycemia which triggers some serious complications both macrovascular and microvascular. Chronic macrovascular complications manifest in the form of coronary heart disease, peripheral vascular disease, stroke, and pulmonary TB. Meanwhile, microvascular complications manifests in the form of retinopathy, diabetic nephropathy, dyspepsia, hypertension, hyperglycemia, hypoglycemia, kidney failure, and gangrenous ulcers the most common one [2], [3], [4], [5]. 
The phenomena show that there has been a significant increase in mortality and health expenditures of diabetic patients in the world. In 2015, the International Diabetes Federation reported that there were 415 million adults aged 20 to 79 with diabetes. Indonesia is among the 10 countries with the high number diabetic patients and is ranked 7th in the world with the number of patients amounted 10.2 million. [6]. In West Sumatra Province, there are about 44 thousand people with DM and around $40 \%$ of them have never been diagnosed [7].

Management of diabetic patients is done by optimizing the pillars of diabetes management including the aspects of education, diet, physical exercise and pharmacological interventions [8]. The benefits of controlling diet were to obtain and maintain blood glucose level normally, to fulfill essential food elements, to obtain the appropriate weight, to cover energy needs [9] However, poor control of blood sugar in diabetic patients mostly occurs in the pillar of diet. This is supported by Lestari's research that reveal that diabetic patients had knowledge (65.5\%), negative attitudes $(58.6 \%)$, discompliance on calories consumption (89.7\%), discompliance on meal schedule (100\%), discompliance on food type consumption (65.5\%), physical activities (55.2\%), and drug compliance (34.5\%). More than $50 \%$ of diabetics have problems controlling their diet [10].

Diabetic patients tended to go on a disproportionate diet, so most respondents fall into the category of poor eating habits leading to the uncontrolled blood glucose conditions [11]. Almost all respondents were not compliant in consuming the number of calories, meal schedules, and types of food [12], [10]. There was a significant relationship between knowledge and attitudes with diet [13]. Other studies showed that respondents who did not comply to the recommended types of food ingredients were caused by their inability to avoid or resist the appetite not to eat sugary food [14]. According to research from Sudaryanto, Setiyadi, \& Frankilawati (2014), lifestyle in urban areas with the consumption of food with high fat, salt, and sugar made people consume food excessively [15].

The reseacher found another phenomenon during her experience in treating patient with diabetic ulcers on her left foot that was eventually amputated. The patient was one of Author patients as home care sevices whose states was in the same as study area. This patient had been treated in hospital for 2 weeks. One of the difficult habits for her to control was related to diet. She admitted that she was unable to control hunger and continue consuming food regardless of the portion or the high sugar content in it. The researcher also found another case of poor diet control when conducting a brief interview with one of the outpatients with uncontrolled blood sugar i.e $234 \mathrm{mg} / \mathrm{dl}$. Mrs. A said " in the morning I often drink tea, sometimes three times a day can. If I don't drink tea, I feel weak. During the night, sometimes I also snack on sweets. It is difficult to change this habit".

In addition, the researcher also got different result with diabetic patients who were able to control their blood sugar, which is $114 \mathrm{mg} / \mathrm{dl}$. Mrs. I said "the important thing is to eat a little rice, lots of vegetables, and fruit, and drink lots of water too. I rarely take my dinner and if I'm hungry, I only eat 5 tablespoons of fried sago. Although many diabetics fail to control their diets, some of them are able to improve their diet and control their blood sugar. Therefore, getting information from them is expected to provide hope and motivation for others. Hence, this study aims to find out and expolore the experience of diabetic patients with controlled blood sugar and diet

\section{METHODS}

This study used qualitative research method with a phenomenological approach. This study used a descriptive phenomenology approach in accordance with the philosophy of its inventor in 1962, Husserl who emphasizes the description of the meaning of one's experience / human [16]. According to Spiegelberg in 1975, descriptive phenomenology stimulates our perceptions of life experiences which emphasize 
richness, depth and breadth of experience [17]. This study illustrates the experience of people with diabetes mellitus in controlling diet and understanding what patients can do to maintain a diet and what is the essence of the experience of diabetes mellitus seen from the patients' perception.

Participants in this study were selected by using purposive sampling which aims to obtain in-depth data related to the phenomenon under study. This sampling is not probability sampling that allows researchers to draw statistical conclusions on the population but will exemplify groups of people who can provide complete information regarding phenomena[18]. Participants were listed from the medical records of diabetic patients in the public health center in the study area. $1^{\text {st }}$ participant was matched with the inclusion criteria. Determination of participants as data sources was assisted by the existence of certain considerations based on predetermined criteria on inclusion criteria [16]. The inclusion criteria in patients with diabetes mellitus in this study are: (a). Patients with diabetes mellitus who have been diagnosed at least 2 years. (b). Ability to control blood sugar when $<200 \mathrm{mg} / \mathrm{dl}$. (c). Patients with diabetes mellitus who do not experience dementia or memory disorders. (d). Ability to tell their experience in controlling their diet with good Indonesian language. Researcher made deal for the first meeting with the $1^{\text {st }}$ participant and informed consent was offered here. Researcher and participant made the schedule for the next meeting dan starting the interview. The $2^{\text {nd }}$ participant would have been started after the $1^{\text {st }}$ participant finished the interview.

There is no provision for the number of participants in qualitative research, but researchers used saturation in determining the number of participants. If saturation is reached with no more information needed, the number of participants is considered sufficient [16]. In this study, the repeating with new information was obtained in 5 th participant. Therefore, the number of participants in this study were 5 .

In this study, the researcher conducted an interview with semi-structured interview technique. The interview begins with an open question, "What is your experience in controlling your diet as a patient with diabetes mellitus?". In this study, the data were analyzed by using Collaizi method, which consists of 7 stages : Transcribing and translation of interviews, extracting significant statements, formulating meanings from significant statements, organizing the aggregate formalized meanings into theme cluster, writing an exhaustive description of the phenomenon, identifying the fundamental structure, validating the exhaustive description with each participant [16].

\section{RESULTS}

There were five diabetic patients participating in this study. The age of participants ranges from 47 years to 72 years. Participants have been diagnosed from 2 years to 20 years. The marital status of the five participants is married. All participants are Muslim and Minangkabau. One is a civil servant, two entrepreneurs and two housewives. The themes obtained from the participants were : 1) self-commitment to discipline and dietary compliance 2) Fruit as an alternative to appetite suppressant, 3) Controlling hunger as a habit, 4) Channeling hunger to activities.

\section{Self-commitment to discipline and dietary compliance}

This theme was obtained when participants recounted their experiences at the beginning of controlling their diet. It was found that participants can maintain their regular diet, discipline with their meal time, regulate meals with a predetermined portion of food to reduce the amount of previous excessive meals, avoid overeating, and use dietary sugars in certain situations. Participants expressed maintaining regular diet as follows:

"I keep eating regularly a 3 times a day. The amount of food is reduced. I follow doctor's advice in eating ". (1.1) (62 Years old, female) 


\section{Proceedings of International Conference on Applied Science and Health}

(№. 4, inl|9)

ICASH

Science for the mankind: Translating research results into policy and practices

Research for Better Society

"The meal is controlled continuously ... we must be able to control it ourselves ... meal time is arranged according to the doctor's rules". (5.1)(47 years old, female)

Participants were discipline with their meal time to maintain and control their diet. The following are participants' statement regarding time and portion discipline:

"I eat 3 times a day, at $8 o^{\prime}$ 'clock in the morning, at 1 or 1.30 in the afternoon, and at $7 \quad$ after maghrib". (1.3) (62 Years old, female)

"I eat according to doctor's rules, a glass of rice in the morning, two glasses in the afternoon, one and a half glasses in the late afternoon. (2.1) (55 years old, Male)

"I eat as needed according to the diet. $3 / 4$ cup of rice in the morning, 1 glass a day, 1 glass a night". (4.1) (72 years old, female)

"I eat 3 times a day, in the morning, afternoon, and late afternoon but not at night. The last meal is around 5 or 6 o'clock...". (5.2) (47 years old, female)

"The food is reduced a little at a time ... About 2 tablespoons of rice. Lots of vegetables, fruit, and water". (1.2) (62 Years old, female)

Participants avoided eating too late at night and maintained this pattern:

"I don't have dinner anymore, there's no snacking at night, that's my diet." (3.3) (51 years old, male)

"I do not have dinner. If I do, my sugar level will go up ". (4.2) (72 years old, female)

"... I no longer consume food at 6 and above. Not any single bite. We have to be able to control ourselves

". (5.4) (47 years old, female)

Participants also expressed using diet sugar as follows:

"After checking into the new doctor, I arranged my meal. He explained that I could not eat much sugar, but I can drink tea or coffee with Tropicana ... When only I really crave for it, I drink it with sugar. " (2.4) (55 years old, Male)

"One time, I had coffee outside using diet sugar that I bring myself". (3.5) (51 years old, male)

\section{Fruit as an alternative appetite suppressant}

This theme was related to participants' reason in choosing fruit as an alternative appetite suppressant. It was found that fruit containing high fiber and can control blood sugar better, so the participants no longer felt worried when blood sugar rises. Fruit chosen as an alternative appetite suppressant were bananas, papaya, apples and oranges. Participants chose fruit as a hunger delay for several reasons, namely doctor's recommendation. The following are participant expressions related to this:

"If I'm hungry, I don't eat again just consume some fruit. I was advised to eat fruit such as , apples, oranges, so if I feel hungry, I will look for fruit". (1.4) (62 Years old, female)

"If I feel like snacking, I usually eat papaya or orange". (2.2) (55 years old, Male)

"Sometimes, when I feel at night, I eati fruit like banana". (3.4) (51 years old, male)

"when hungry, I occasionally eat fruit such as papaya or apple." (4.4) (72 years old, female)

\section{Controlling hunger as a habit}

This theme was obtained as participants' efforts to make new habits in controlling thei hunger. The efforts included not eating large portions or choosing sweet foods. It is expressed as follows:

"If you get used to it, you will no longer feel hungry. It's normal to feel discomfort at first ... Recently, I was sick, and the doctor told me not to eat. And I am fine with it ". (1.5) (62 Years old, female)

"Maybe I am getting used to it. It's been 4 years or more, so I am able to control my hunger and eat less ". (2.5) (55 years old, Male) 
"... I have probably get used to not eating a lot, so it doesn't bother me". (3.7) (51 years old, male)

\section{Channeling hunger to activities}

This theme was derived from participant statement regarding their daily activities and exercise to control hunger and maintain normal blood sugar levels. These activities included focusing on work and walking around. The following are participant statement related to daily activities to control their hunger:

"I run small shops at home, so it makes me busy. Because of the busy work, I no longer feel hungry". (1.6) (62 Years old, female)

"My busy routines and can divert my hunger, but sometimes I also walk around and move a lot". (3.8) (51 years old, male)

Participants also exercise to channel hunger as it is expressed as follows:

"... I sometimes take a walk around the neighborhood to reduce my hunger". (2.6) (55 years old, Male)

"I do some activities to forget about hunger, ...". (3.6) (51 years old, male)

"Yes, at least I clean up my house and move a lot to get sweaty". (5.5) (47 years old, female)

\section{DISCUSSION}

\section{Self-commitment to discipline and dietary compliance}

Some participants controlled their diet by eating regularly and following doctor's rules and nutritionists. Participants set their meal time 3 times a day on a regular basis with appropriate portion, vegetables, and fruits. Participants arrannged their portion meal by using a glass or 2-3 tablespoons of rice.

Meal arrangement describes dietary or eating habits including the type and frequency of eating [19]. Meal is arranged by adjusting it to the recommended portion, which is usually less than the usual portion. For example, some participants reduced their carbohydrate intake such as reduce portions of rice and high carbohydrated snacks. They avoided eating at night as an effort to maintain normal blood sugar levels. Participants also used diet sugar when they wanted to consume sweet beverage like tea or coffee. Through these, the participants hope that they can maintain their blood sugar level within the normal limit.

It is supported by other studies that reveal that the majority of respondents comply with theu due to their desire to reduce their blood sugar level $[10,11]$. Other related research find that people with good diet are 4 times more succeed in the management of type 2 diabetes mellitus compared to those with poor diet [21]. Therefore, diabetics can control diabetes mellitus, if they are able to comply with meal arrangements and change their eating habits better.

Participants can obtain compliance from education, information sources, and mass media [22]. The indicator of compliance is following instructions regularly. Compliance includes the use of insulin, diet, physical exercise and health education. Compliance with the diet is not eating too much food and controlling blood sugar [23]. Meanwhile, discipline is a form of obedience to the rules both written and unwritten one. The amount of food is set based on height, weight, type of activity, and age and calculated as well as determined the exact number of calorie needed in a day. People with diabetes are recommended to restrict the consumption saturated fat, cholesterol and fried foods [24]. With arranging their meal portion, type and time, the participant can maintain blood glucose and lipid levels within normal limit. They also expect that changes in better eating habits can have a positive impact on them. 


\section{Fruit as an alternative appetite suppressant}

Participants in this study experienced problems in controlling their hunger in their diet. Fruit can be consumed to reduce their appetite for heavy meal before meal time. In addition, participants consumed fruits because the doctor recommend them. Fruit with high fiber good for people with diabetes mellitus. The fruit chosen by participants consisted of: bananas, papaya, apples, and oranges because their price is affordable, easy to get, and good flavor. Fruits and vegetables are recommended for diabetics because they contain minerals, vitamins and can slow glucose absorption [24]. The fruit recommended is less sugary ones classified into the B fruit group such as: papaya, kedondong, bananas (except pisang raja, pisang tanduk, pisang emas), apples, tomatoes, guava, guava, salak, belimbing, and bengkoang [19]. A high-fiber diet shows a good effect on glycemic control. Fiber can not be digested but will be absorbed by the small intestine. It will then be fermented, produce fatty acids and be absorbed back into the bloodstream. This has a good effect on long-term decreases in blood sugar levels and insulin sensitivity [25].

\section{Controlling hunger as a habit}

Participants in this study have experienced diabetes mellitus with a very long period of time from 2 to 20 years. With different age and gender, participants also control hunger differently. In addition to controlling the diet, participants also get used to themselves to control hunger. Most participants can control hunger due to their long-suffering illness and their attitude in running the DM diet regularly. It formed a new personality in which participants can control their appetite. Participants mentioned that they did not feel burdened with the rules of eating and can go on a diet by controlling their hunger. They believed that the work done with good intentions repeatedly can form new habits with the goa to maintain normal blood sugar levels.

It is supported by other studies that reveal that someone who has been diagnosed with diabetes mellitus for a long time has a routine embedded in their personal lives [26]. If a person feels the benefit of a change in behavior, it will be maintained [27]. Other related state that attitudes are not born from birth but can be learned and formed based on individual experience throughout their life-long development. Formation of attitudes is influenced by external factors (experience, situation, norms, obstacles and reward) and internal (physiological, psychological and motive) [28].

\section{Channeling hunger to activities}

Diabetes mellitus needs to be overcome by controlling the diet. Participants controlled the diet and did light activities with the aim of controlling hunger and blood sugar. Besides overcoming hunger by consuming fruit, participants also carried out daily activities and walked around. This method was chosen by participants to overcome the feeling of hunger. They felt that doing light activities can divert perceptions of hunger and prevent the desire to consume foods that were sweet or excessive. For participants, the activity carried out has a positive effect and does not harm them. Walking can stabilize blood pressure, cholesterol, stress and depression and help promote weight loss and the risk of chronic illness. Walking for 10 minutes every day can provide fitness for diabetics [29].

It is supported by other studies that state that regular exercise (more than 3 times a week for 30 minutes) will improve carbohydrate metabolism, has a positive effect on lipid metabolism, and contribute to weight loss [30]. Other studies reveal that elderly patients with diabetes mellitus will experience difficulties when doing physical exercise / exercise compared to those in younger ages [26]. In addition, the reason for diabetics not doing heavy exercise is due to physical limitations. Exercise in diabetes must be adjusted to ability and gradually increase [19]. Another study reveal that some respondents do not exercise because of their busy routinity [19]. Physical exercise can maintain fitness, have an impact on weight loss, and improve insulin sensitivity. This will have an impact on improving the control of glucose in the blood [8]. 


\section{Integrity of Research Results with Nursing Theory \\ The Theory of Health Belief Model (HBM)}

The concept of HBM theory proposes that health behavior is determined by personal beliefs or perceptions of the disease and strategies available to reduce disease. HBM theory is based on someone who will take an action related to his health [31]. In this study, participants have health problems i.e diabetes mellitus. Based on the results of the themes obtained, participants took action related to their health, an action to maintain normal blood sugar levels through diet control.

HBM theory has 6 components, namely perceived perceived susceptibility, perceived severity, perceived benefism, perceived barriers, cues to action, and self efficacy [31]. Participants in this study made behavioral changes to diet control and found that they would benefit from controlled blood sugar. This is in accordance with the components of HBM theory namely perceived benefism. When making behavioral changes, especially changes in old diet patterns to current diet patterns, participants face a major obstacle, namely hunger. This hunger barrier is in accordance with the components of HBM theory, namely perceived barriers. However, participants are able to overcome this obstacle by diverting hunger through activities and sports forming a new habit. Participants feel that they can cope with and maintain a diet that prescribed by health workers. The actions taken by participants to control the diet are influenced by the existence of guidance from health workers on how to go on diet for diabetics. Participants maintain a dietary pattern as they have gotten through health workers when they check up to the hospital. This is in accordance with the components of HBM theory, namely cues to action. The commitment of participants to discipline and adherence to a regular diet are related to the presence of self efficacy in participants. There is confidence in a diabetic diet so discipline and dietary compliance can be maintained.

Participants in this study have positive behaviors in which they can control their diet by making behavioral changes in forming habits. The habit focuses on the problem of controlling hunger which is initially difficult. It stimulates participants to make behavioral changes gradually. If the participant feels that the previous behavior has a negative impact on health, they will begin to condition their behavior towards the disease. They take such action due to the fatality of the disease. If left untreated include, there will other consequences including medical consequences, psychological consequences and social consequences. The greater the perception that the problem is a threat, the better the action the patient take [32].

\section{CONCLUSSION}

In this study there were four themes obtained: Self-commitment to discipline and dietary compliance, Fruit as an alternative appetite suppresant, Controlling Hunger as a Habit, and Channelling hunger to activities. Controlling diet for participants has been succesfully done by created a new habit through controlling their hunger, so that they could keep their commitment dan disclipline for dietary compliance, choosing fruits as alternative suppresant and doing activity for channeling the hunger. Therefore it is important for the nurses to educate the diabetic patients about how to deal with diet issues through controlling a hunger as a habit. The themes obtained are in accordance with the theory of health behavior change i.e the theory of Health Belief Model in which participants are able to make changes in behavior towards diet control in an effort to maintain normal blood sugar levels. The results of this study are expected to motivate other diabetics who have not succeeded in controlling their diets. 


\section{Proceedings of International Conference on Applied Science and Health}

(No. 4, ?이리

ICASH

Science for the mankind: Translating research results into policy and practices

Research for Better Society

\section{REFERENCES}

1. WHO. Diabetes Programme: Country and Regional Data. World Health Organization. 2016

2. Edwina DA, Manaf A, Efrida. Pola Komplikasi Kronis Penderita Diabetes Melitus Tipe 2 Rawat Inap di Bagian Penyakit Dalam RS. Dr. M. Djamil Padang (the pattern of Chronic complication Diabetes sufferer Type 2 inpatient in disease section in RS. Dr. M. Djamil Padang). Jurnal Kesehatan Andalas. 2012; 4(1).

3. Rosyada A, Trihandini I. Determinan Komplikasi Kronik Diabetes Melitus pada Lanjut Usia (The determination of chronic complications of Diabetes mellitus in elderly). Jurnal Kesehatan Masyarakat Nasional. 2013; 7(9).

4. Rajasa RE, Afriwardi, Zein SB. Hubungan Tingkat Keteraturan Berolahraga terhadap Komplikasi Penyakit pada Pasien DM Tipe 2 di Poliklinik Endokrin Rsup Dr.M.Djamil Padang (Relation of regularity of exercise to complications of diseases of type 2 DM patients in endocrine clinic of Rsup Dr. M. Djamil Padang). Jurnal Kesehatan Andalas. 2016; 5(2).

5. Novitasari R. Hubungan antara Pengetahuan dan Sikap dengan Kepatuhan Diit Diabetes Melitus (DM) pada Lanjut Usia (Lansia) di Kelurahan Gayam Kecamatan Sukoharjo (The relationship between knowledge and attitudes to Diet Diabetes mellitus (DM) on seniors in the village Gayam Sukoharjo District). Surakarta; Universitas Muhammadiyah Surakarta; 2015.

6. Huang Y, Ogurtsova K, Fernandes JDA, Cavan D, Makaroff LE, Shaw J, Cho NH. IDF Diabetes atlas estimates for the global Diabetes prevalence of adult age 18-99 years old. International Diabetes Federation. 2015.

7. Kemenkes RI. Info Datin; Situasi Dan Analisis Diabetes (Diabetes Situations and analysis). Jakarta Selatan; Kementrian Kesehatan Republik Indonesia. 2014.

8. Perkeni. Konsesus; Pengelolaan dan Pencegahan Diabetes Melitus Tipe 2 (type 2 Diabetes mellitus Management and prevention). Indonesia; Perkumpulan Endokrinologi Indonesia. 2015.

9. Azila. Gambaran kualitas hidup pasein diabetes mellitus tipe 2 di poli interne RS. Soebandi (Description of the quality of life type 2 diabetes mellitus in Soebandi Hospital). Jember ; Universitas Jember; 2016.

10. Lestari D, Citrakesumasari, Alharini S. Upaya Penanganan dan Perilaku Pasien Penderita Diabetes Melitus Tipe 2 di Puskesmas Maradekaya Kota Makassar (Treatment of type 2 Diabetes mellitus patient's care and behaviour in Puskesmas Maradekaya city Makassar). Jurnal Kesehatan. 2013.

11. Anani S, Udiyono A, Ginanjar P. Hubungan antara Perilaku Pengendalian Diabetes dan Kadar Glukosa Darah Pasien Rawat Jalan Diabetes Melitus (The relationship between Diabetes control behaviour and patient blood glucose level Diabetes mellitus). Jurnal Kesehatan Masyarakat. 2012;1(2): 466-478.

12. Sari ADP, Citrakesumasari, Alharini S. Upaya Penanganan dan Perilaku Pasien Penderita Diabetes Melitus Tipe 2 di Puskesmas Maccini Sawah Kota Makassar (Treatment and behavior efforts of type 2 Diabetes mellitus patients in the community health centers in Makassar). Jurnal Kesehatan. 2013

13. Wiro G, Arundina A, Putri EA. Hubungan antara Pengetahuan dan Sikap dengan Perilaku Pencegahan Diabetes Melitus pada Pegawai Negeri Sipil di Wilayah Kerja Puskesmas Siantan Hulu (The relationship between knowledge and attitudes to Diabetes mellitus prevention in civil servants in the working area of Siantan Hulu). Pontianak: Universitas Tanjungpura; 2013

14. Fachruddin II, Citrakesumasari, Alharini S. Upaya Penanganan dan Perilaku Pasien Penderita Diabetes Melitus Tipe 2 di Puskesmas Bara-Baraya Kota Makassar (Treatment of type 2 Diabetes mellitus in the health centers of Bara-Baraya Makassar City). Jurnal Kesehatan. 2013.

15. Sudaryanto A, Setiyadi NA, Frankilawati DA. Hubungan antara Pola Makan, Genetik dan Kebiasaan Olahraga terhadap Kejadian Diabetes Melitus Tipe II di Wilayah Kerja Puskesmas Nusukan Banjarsari (The relationship between diet, genetic and exercise habits of Diabetes mellitus type II in the work area of health centers Nusukan Banjarsari). Jurnal. Fakultas Teknik Universitas Wahid Hasyim Semarang. 2014.

16. Polit DF, Beck CT. Nursing Research: Principles And Methods (7 Th Ed.). Philadelphia: Lippincitt Williams \& Wilkins; 2010.

17. Streubert HJ, Carpenter DR. Qualitative research in nursing. Philadelphia; Lippincott Williams \& Wilkins; 2011

18. Creswell JW. Research design; Pendekatan kualitatif, kuantitatif dan mixed. Yogyakarta: Pustaka Pelajar; 2014.

19. Putri NHK, Isfandiari MA. Hubungan Empat Pilar Pengendalian Diabetes Melitus Tipe 2 dengan Rerata Kadar Gula Darah (Relationship of four pillars of type 2 Diabetes mellitus control with average blood sugar levels). Jurnal Berkala Epidemiologi. 2013; 1(2): $234-243$.

20. Sugiyarti, Meikawati M, Salawati T. Hubungan Ketaatan Diet dan Kebiasaan Olahraga dengan Kadar Gula Darah padaPasien Diabetes Mellitus yang Berobat DiPuskesmas Ngembal Kulon Kabupaten Kudus (Relationship Obedience Diet and exercise habits with blood sugar levels of Diabetes Mellitus treatment DiPuskesmas Ngembal Kulon Kudus Regency). Jurnal Kesehatan Masyarakat Indonesia. $2011 ; 7(1)$.

21. Utomo AYS. Hubungan antara 4 Pilar Pengelolaan Diabetes Melitus dengan Keberhasilan PengelolaanDiabetes Melitus Tipe 2 (The relationship between the 4 pillars of Diabetes mellitus management with the successful manageability of type 2 Diabetes mellitus). Univer Semarang: Universitas Diponegoro; 2010.

22. Senuk A, Supit W, Onibala F. Hubungan Pengetahuan dan Dukungan Keluarga denganKepatuhan Menjalani Diet Diabetes Melitus DiPoliklinik Rsud Kota Tidore Kepulauan Provinsi Maluku Utara (Relationship of knowledge and family support with Adherence to the Diabetes mellitus Diet and the city of Tidore of the North Maluku Islands). Ejournal Keperawatan (E-Kp). 2013; 1(1).

23. Risnasari N. Hubungan Tingkat Kepatuhan Diet Pasien Diabetes Mellitus dengan Munculnya Komplikasi Di Puskesmas Pesantren II Kota Kediri (Relationship of level Compliance Diet diabetic patient with the emergence of complications in the Puskesmas Pesantren II Kota Kediri). Jurnal Universitas Nusantara PGRI Kediri. 2014; 1(25).

24. Mu'in M, Nursasi AY, Wiarsih W. Gambaran Perilaku Manajemen Perawatan Penderita DM (Overview of DM Care Management behaviour). Jurnal Keperawatan Soedirman. 2014; 9(1).

25. Fitri RI, Wirawanni Y. Asupan Energi, Karbohidrat, Serat, Beban Glikemik,Latihan Jasmani dan Kadar Gula Darah padaPasien Diabetes Mellitus Tipe 2 (Energy intake, carbohydrates, fiber, glycemic load, physical exercise and blood sugar levels of type 2 Diabetes Mellitus). Semarang: Universitas Diponegoro; 2012. 


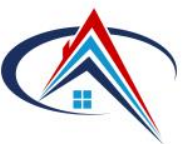

ICASH

\section{Proceedings of International Conference on Applied Science and Health}

(No. 4, ?이리

Science for the mankind: Translating research results into policy and practices

Research for Better Society

26. Putri DSR, Yudianto K, Kurniawan T. Perilaku Self-Management Pasien Diabetes Melitus (Self-Management of Diabetic Patient). Jurnal Fakultas Keperawatan Universitas Padjadjaran. 2013; 1(1).

27. Tera BHA, Noer ER. Determinan Ketidakpatuhan Diet Penderita Diabetes Melitus Tipe 2(Determination of non-compliance with type 2 Diabetes mellitus ). Semarang: Universitas Diponegoro; 2011.

28. Aini N, Fatmaningrum W, Yusuf AH. Upaya Meningkatkan Perilaku Pasien dalam Tatalaksana Diabetes Mellitus dengan Pendekatan Teori Model Behavioral System Dorothy E. Johnson (Efforts to improve patient behaviour in the treatment of Diabetes Mellitus with theoretical approach to Model Behavioral System Dorothy E. Johnson). Jurnal Ners. 2011; 6(1).

29. ADA. a day in the life of diabetes by Jay Dickman. American Diabetes Association. 2015.

30. Suryani N, Pramono, Septiana S. Diet dan Olahraga sebagai Upaya Pengendalian Kadar Gula Darah pada Pasien Diabetes Melitus Tipe 2 Di Poliklinik Penyakit dalam RSUD Ulin Banjarmasin (Diet and exercise as an effort to control blood sugar levels in type 2 Diabetes mellitus patients in polyclinics of the disease in RSUD Ulin Banjarmasin). Jurnal Kesehatan Masyarakat Indonesia. 2016; 6(2).

31. Glanz K, Lewis FM, Rimer BK. Health Behavior and Health Education; Theory, Research and Practice. San Francisco: Jossey-Bass Publisher; 1997

32. Sholihah M. Gmbaran Peluang Perubahan Perilaku Perokok dengan Health Belief Model pada Pasien Hipertensi Di Puskesmas Ciputat Tangerang Selatan (The opportunity to change smokers ' behavior changes with Health Belief Model in hypertension patients at Puskesmas South Tangerang). Jakarta:. Universitas Islam Negeri Syarif Hidayatullah Jakarta; 2014 